\title{
PENGGUNAAN MOTOR DC BRUSHLESS SUNNY SKY X2212-13 KV: 980 II PADA PERANCANGAN QUADCOPTER
}

\author{
Qori Dermawan, Muhammad Sadli, Andik Bintoro \\ Jurusan Teknik Elektro, Fakultas Teknik Universitas Malikussaleh \\ Kampus Bukit indah, Jalan Batam No. 16 Kecamatan Blangpulo Lhokseumawe \\ E-mail : msadli@unimal.ac.id
}

\begin{abstract}
Abstrak - perancangan quadcopter dibutuhkan motor dengan kecepatan yang tinggi serta kontruksi dalam skala kecil oleh sebab itu digunakan motor DC jenis brushless, motor brushless ini diatur menggunakan teknik PWM (Pulse Widht Modulation) untuk mendapatkan RPM yang tinggi secara konstan. Meotde yang digunakan dalam perancangan ini adalah trial and error yang berfungsi untuk mencari data akurat pada motor saat melakukan beberapa manuver seperti, Throrrle, Yaw, Pitch, dan Roll. Hasil data yang didapatkan berupa, bentuk gelombang, frekuensi, perioda dan tegangan pada masing-masing motor dengan menggunakan beberapa asumsi yang disesuiakan pada pedal gas remote control.
\end{abstract}

\section{Keywords - Motor Brushless DC, Quadcopter, Trial and Error, Remote Control}

\section{PENDAHULUAN}

Seiring perkembangan teknologi, kebutuhan akan motor yang memiliki efesiensi,torsi, kecepatan tinggi dan dapat divariasikan, serta biaya perawatan rendah semakin meningkat. Hanya saja motor yang digunakan secara umum saat ini, yakni motor DC dan motor induksi belum dapat memenuhi kebutuhan tersebut.

Motor DC, memiliki efesiensi tinggi karena penggunaan tegangan DC pada rotor untuk menggerakan motor tersebut, tetapi motor DC memiliki biaya perawatan yang tinggi. Biaya perawatan yang tinggi ini muncul akibat digunakannya sikat dalam komutasi motor DC. Sikat pada motor DC ini cepat mengalami kerusakkan karena pada saat berputar, pada sikat akan timbul percikkan api.

Oleh karena itu untuk merancang quadcopter dibutuhkan motor yang kecil tetapi memiliki kecepatan yang tinggi. Untuk memenuhi kebutuhan ini motor yang memiliki efesiensi tinggi, torsi tinggi dan biaya perawatan rendah maka digunkan motor DC brushless kriteria tersebut tidak terdapat pada motor brushed dikarenakan motor jenis brushed memiliki putaran yang rendah, dan jika merancang quadcopter membutuhkan gear tambahan.

Konstruksi motor brushless DC terdiri dari stator yang terbuat dari kumparan dan rotor terbuat dari magnet permanen. Sumber tegangan utama motor BLDC adalah tegangan DC, motor BLDC memiliki back EMF trapezoidal. Agar motor BLDC dapat bekerja diperlukan adanya medan putar magnet stator. Pengendalian tegangan motor BLDC yakni menggunakan metode six-step dan metode PWM.
Kecepatan motor BLDC dapat diatur dengan menggunakan teknik PWM sebagai input untuk memvariasikan tegangan DC sebagai masukan untuk motor brushless DC. Pengaturan ecepatan motor dapat dilakukan dengan cara mengubah besarnya tegangan input yang diberikan pada motor BLDC sesuai dengan kecepatan motor yang diingikan untuk melakukan semua pergerakkan dari quadcopter. Pengaturan kecepatan motor juga dilakukan dengan mengubah besarnya duty cycle pulsa. Pulsa yang berubah-ubah (duty-cycle)nya ini menentukan kecepatan sebuah motor brushless. Untuk itu pada perancangan quadcopter ini penulis menggunakan jenis motor DC brushless Sunny sky dengan tipe X 2212-13 KV: 980 II dengan daya maximum 150 Watt.

Quadcopter adalah sebuah Miniatur Aerial Vehicle (MAV) yang mempunyai 4 buah baling-baling (propeller). Sebuah remote control (RC) diperlukan sebagai pengendali quadcopter untuk bisa melakukan manuver maju, mundur, kiri, kanan, atas, bawah, dan juga berotasi oleh sebab itu tegangan yang disupply oleh sebuah baterai untuk menghidupkan motor brushless pada quadcopter akan berpengaruh terhadap kinerja pada quadcopter. (Joko, 2017)

\section{DASAR TEORI}

\section{Unmanned Aerial Vehicle (UAV)}

Unmanned Aerial Vehicle (UAV) atau kendaraan udara tanpa awak adalah salah satu teknologi yang sedang mengalami perkembangan yang pesat dan memiliki potensi yang sangat besar, baik untuk keperluan militer maupun kepentingan lainnya, kelebihan UAV adalah dapat digunakan pada misi-misi berbahaya tanpa membahayakan pilot/manusia.

UAV awal dibuat kebanyakan untuk kepentingan militer. Seiring berkembang teknologi dan banyak penelitian yang berkaitan dengan UAV, sekarang UAV memiliki fungsi yang berbeda-beda, salah satu adalah transportasi UAV yang dapat mengangkut pada bagian pesawat, namun untuk UAV jenis helikopter dapat mengangkut barang diluar badan pesawat. Beban yang diberikan pada UAV ini biasa beban yang tergolong ringan dan membutuhkan kecepatan pengiriman dan resiko pengiriman yang tinggi.

UAV dapat digunakan pada daerah berbahaya yang apabila dilakukan dengan pesawat berawak akan membahayakan keselamatan awak pesawat tersebut. Daerah yang berbahaya tersebut daerah pada ketinggian yang 
berbahaya. Ada banyak tipe dari UAV, diantaranya fixed wing, axial wing, coaxial wing, dan quadrotor. (Yulistiyanto, 2013)

\section{Quadcopter}

Quadcopter adalah salah satu jenis rotor craft yang memiliki 4 buah rotor sebagai penggerak propeller yang menghasilkan gaya angkat. Quadcopter dapat melakukan take off dan landing secara vertical. Vertical Take Off Landing (VTOL) Aircraft merupakan jenis pesawat yang dapat melakukan take off dan landing tegak lurus terhadap bumi sehingga dapat dilakukan pada tempat yang sempit seperti: Helicopter, Tricopter, Quadcopter, dan beberapa fixed wing dengan mesin jet termasuk kategori jenis ini. (Quadcopter).

\section{Quadcopter movement}

Gerakan throttle merupakan gerak translasi quadcopter sepanjang sumbu z, gerakan ini dipengaruhi oleh perubahan kecepatan keempat rotor dengan nilai kecepatan putaran yang sama. Dengan pergerakan throttle, quadcopter akan dapat melakukan akselerasi naik atau turun sesui dengan tingkat kecepatan rotor. Gerakan roll merupakan gerakan rotasi pada sumbu x gerakan ini dipengaruhi oleh perubahan kecepatan rotor kanan dan kiri. Gerakan pitch merupakan gerakan rotasi pada sumbu y, gerakan ini dipengaruhi oleh perubahan kecepatan pada motor depan dan belakang, sedangkan yaw merupakan gerakan rotasi pada sumbu z.

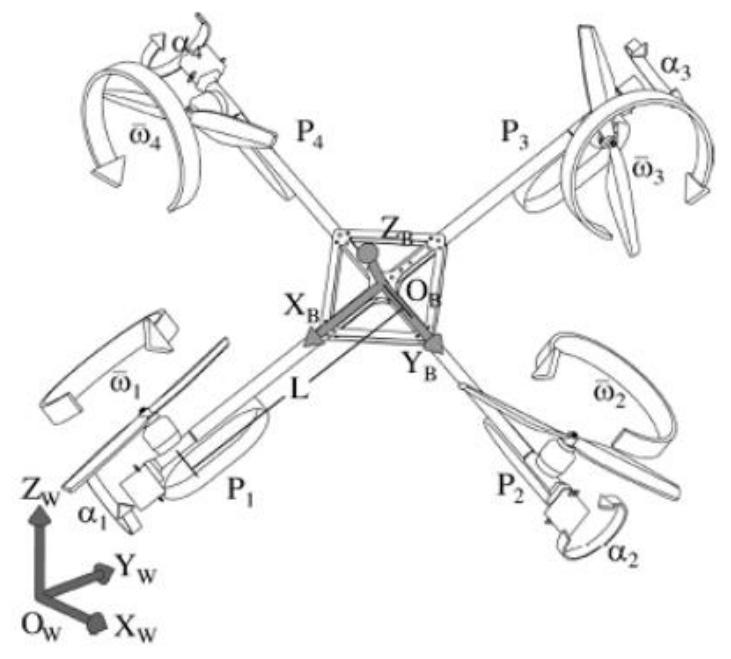

Gambar 2.1 Pola Terbang Quadcopter

Pola terbang quadcopter untuk manuver atau bergerak mempunyai aturan khusus berdasarkan pergerakan rotor pada keempat sisinya.

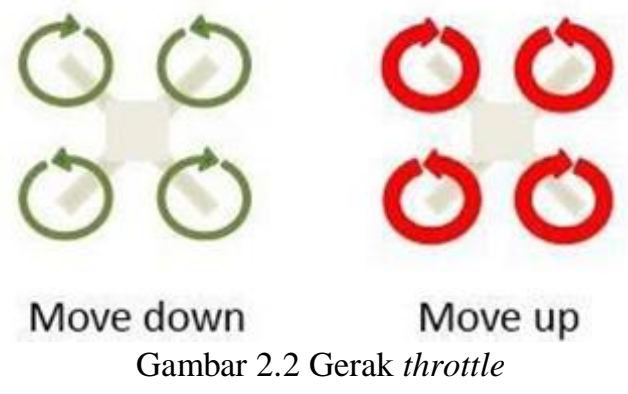

Gerak Thorttle adalah gerak menaikkan atau menurunkan ketinggian dengan mengatur kecepatan keempat rotor sama besar. Quadcopter akan bergerak searah sumbu z dengan mengacu pada koordinat quadcopter. Arah putar masingmasing rotor seperti pada gambar 2.2.

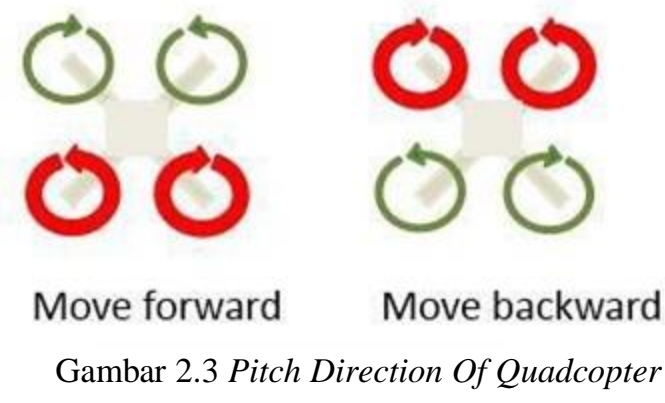

Pitch adalah gerak yang hampir sama dengan roll. Penerapan pitch pada manuver quadcopter adalah dengan meningkatkan atau menurunkan kecepatan putar rotor bagian depan atau belakan secara bersama dan kecepatan sama seperti yang terlihat pada gambar 2.3.

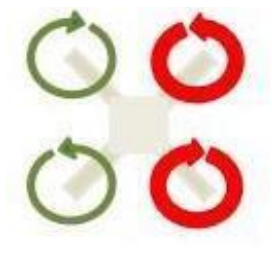

Bend left

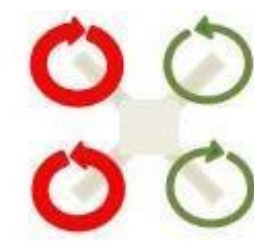

Bend Right
Gambar 2.4 Yaw Direction Of Quadcopter

Yaw (Ф) adalah gerak manuver kesamping dengan cara mengikatkan kecepatan putar bagian kiri atau kanan quadcopter dengan bersamaan seperti yang dilihat pada gambar 2.4. 


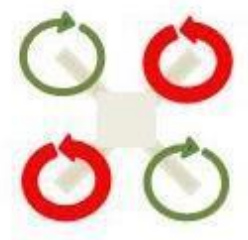

Rotate left

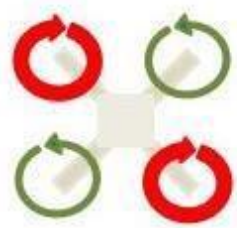

Rotate right
Gambar 2.5 Roll Direction Of Quadcopter

Roll adalah gerakan dengan cara meningkatkan kecepatan putar rotor dengan posisi bersilangan secara bersama-sama. Tujuan gerak ini adalah mendapatkan manuver quadcopter berputar searah atau berlawanan jarum jam seperti yang terlihat pada gambar 2.5.

\section{Mathematical modeling quadcopter}

Pemodelan secara fisik terbilang kompleks dan apabila tanpa ada asumsi yang digunakan untuk menyediakan persamaan, perhitungan menjadi tidak praktis. Beberapa asumsi yang digunakan dalam pemodelan ini adalah:

1. Struktur dari quadcopter dikatakan rigid

2. Struktur dari quadcopter dikatakan simetris

3. Struktur dari propeller dikatakan rigid

4. Gaya thurst dan drag adalah proporsional dengan kuadrat dari kecepatan propeller.

5. Defree of freedom (DoF), gerakan skematik quadcopter diwakili dalam gambar 2.6 dan berdasarkan ini skematis, pemodelan matematika quadcopter diperoleh dengan cara sebagai berikut.

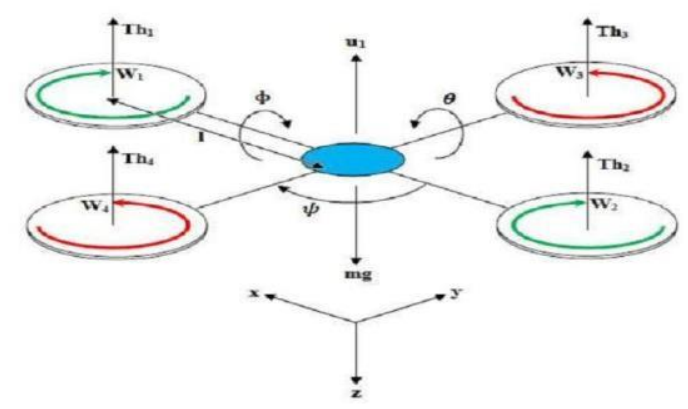

Gambar 2.6 Skema Quadcopter

Keterangan:

U1 : Jumlah tekanan dari setiap motor

Th1 : Dorongan yang dihasilkan oleh motor depan

Th2 : Dorongan yang dihasilkan oleh motor belakang

Th3 : Dorongan yang dihasilkan oleh motor kanan

Th4 : Dorongan yang dihasilkan oleh motor kiri

m : Massa Quadcopter

g : Percepatan Gravitasi

1 : Panjang setengah dari quadcopter

$\mathrm{x}, \mathrm{y}, \mathrm{z}$ : Tiga posisi

$\Theta, \Phi, \Psi$ : Tiga sudut eurel mewakili pitch, roll, and yaw

\section{Quadcopter dynamics}

Dinamika quadcopter adalah keadaan dimana quadcopter berusaha mempertahankan gerakan di udara berdasarkan leveling awal. Pada dinamika quadcopter, terdapat persamaan kinematik dan dinamik. Kinematik berhubungan dengan posisi gerak, sedangkan dinamik berhubungan dengan posisi. Untuk persamaan kinematik sebagai berikut:

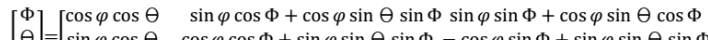
$\left[\begin{array}{l}\Theta \\ \varphi\end{array}\right]=\left[\begin{array}{cc}\sin \varphi \cos \theta & \cos \varphi \cos \Phi+\sin \varphi \sin \theta \sin \Phi-\cos \varphi \sin \phi+\sin \varphi \sin \theta \sin \Phi\end{array}\right.$

Variable $\Phi, \Theta$ dan sedangkan $\mathrm{u}, \mathrm{v}$ dan $\mathrm{w}$ adalah percepatan pada frame quadcopter. Selanjutnya dibawah ini adalah transfer matriks dari persamaan (2.1), dimana $\mathrm{p}$, q, dan $\mathrm{r}$ adalah kecepatan pada masing-masing posisi.

$\left[\begin{array}{l}\Phi \\ \Theta \\ \varphi\end{array}\right]=\left[\begin{array}{rrc}1 & \sin \Phi \tan \Theta & \cos \Phi \tan \theta \\ 0 & \cos \Phi & -\sin \Phi \\ 0 & \sec \Phi \sin \Theta & \sec \Phi \cos \theta\end{array}\right]\left[\begin{array}{l}\mathrm{p} \\ \mathrm{q} \\ r\end{array}\right]$

Untuk dinamika quadcopter persamaan sebagai berikut:

$$
\mathrm{F}=m \frac{d v}{d t \beta}
$$

$\mathrm{m}$ adalah massa dari sistem yang digunakan, a adalah percepatan gerak, dan $\mathrm{F}$ adalah gaya yang terjadi pada sistem. Sehingga persamaan dapat ditulis.

$$
\left[\begin{array}{c}
\mathrm{Fx} \\
\mathrm{Fy} \\
F z
\end{array}\right]=m \frac{d v}{d t 0}=\mathrm{m}\left(\left[\begin{array}{l}
u \\
v \\
w
\end{array}\right]+\left[\begin{array}{l}
p \\
q \\
r
\end{array}\right] x\left[\begin{array}{l}
u \\
v \\
w
\end{array}\right]\right)
$$

Sehingga percepatan liniear dari quadcopter dapat dihitung:

$\left[\begin{array}{l}u \\ v \\ W\end{array}\right]=\frac{1}{m}\left[\begin{array}{l}\mathrm{Fx} \\ \mathrm{Fy} \\ F z\end{array}\right]-\left[\begin{array}{l}q w-r v \\ p w-r u \\ p v-q u\end{array}\right]$

$\mathrm{M}$ adalah torsi yang terjadi, dan $\mathrm{h}$ merupakan momentum putar. Dengan menggunakan persamaan coriolis didapat:

$$
\begin{gathered}
\mathrm{M}=\frac{d v}{d t 0}=\frac{d h}{d t \mathrm{~b}}+\mathrm{w} \times \mathrm{h} \\
{\left[\begin{array}{c}
M x \\
M y \\
M z
\end{array}\right]=1\left[\begin{array}{l}
p \\
q \\
r
\end{array}\right]+\left[\begin{array}{l}
p \\
q \\
r
\end{array}\right] \times 1\left[\begin{array}{l}
p \\
q \\
r
\end{array}\right]}
\end{gathered}
$$

Sehingga

$$
\left[\begin{array}{l}
p \\
q \\
r
\end{array}\right]=1^{-1}\left[\begin{array}{l}
M x \\
M y \\
M z
\end{array}\right]-1^{-1}\left[\begin{array}{l}
p \\
q \\
r
\end{array}\right] \times 1\left[\begin{array}{l}
p \\
q \\
r
\end{array}\right]
$$

\section{Brushless Motor}

Motor Brushless Direct Current (BLDC) adalah motor yang tidak menggunakan sikat brush untuk pergantian medan magnet (Komutasi) tetapi dilakukan secara komutasi elektrolis, motor yang digunakan pada perancangan ini dapat dilihat pada gambar 2.7. 


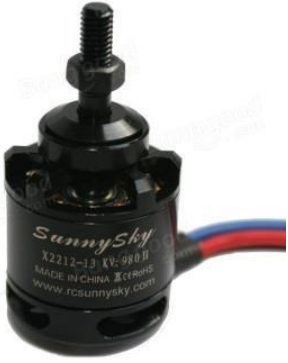

Gambar 2.7 Motor SunySky

Tabel 2.1 Spesifikasi Motor Sunny Sky

\begin{tabular}{|l|l|}
\hline \multicolumn{1}{|c|}{ Parameter } & \multicolumn{1}{c|}{ Nilai } \\
\hline KV & 980 \\
\hline Konfigurasi & $12 \mathrm{~N} 14 \mathrm{P}$ \\
\hline Diameter Stator & $22 \mathrm{~mm}$ \\
\hline Panjang Stator & $12 \mathrm{~mm}$ \\
\hline Diameter Poros & $3 \mathrm{~mm}$ \\
\hline Dimensi Motor & $27.5 \times 30 \mathrm{~mm}$ \\
\hline Berat & $56 \mathrm{gr}$ \\
\hline Arus Maksimal & $15 \mathrm{~A}$ \\
\hline Daya Maksimal & $150 \mathrm{~W}$ \\
\hline Internas Resistan & $126 \mathrm{~m} \Omega$ \\
\hline Idle Current (10)@ 10 V(A) & 0.3 \\
\hline No of Celss (Li-Po) & $2-3$ Sell \\
\hline
\end{tabular}

Perbedaan utama antara motor DC magnet permanent (DC-MP) dengan motor I DC adalah terletak pada pembangkitan medan magnet untuk meghasilkan gaya gerak. Jika pada motor DC-MP medan magnet yang dikontrol berada di rotor dan medan magnet tetap berada di stator. Sebaliknya motor brushless menggunakan pembangkitan medan magnet stator untuk mengontrol geraknya sedangkan gerak magnet tetap berada di rotor. (Pitowarno, 2006) motor BLDC mempunyai banyak keuntungan dibandingkan dengan motor DC lainnya. (Yulistiyanto, 2013) (Nurhayati, 2014) yaitu:

1) Kecepatan yang lebih baik untuk melawan karakteristik tenaga putaran.

2) Tanggapan dinamis tinggi.

3) Efisiensi tinggi.

4) Tahan lama atau usia pakai lebih lama.

5) Nyaris tanpa suara bila dioperasikan.

6) Speed range yang lebih luas.

\section{Perbedaan dengan brushed motor}

Perbandingan tenaga putaran lebih besar dibanding dengan ukuran motor, dengan ukuran motor yang relatif kecil dapat meghasilkan torsi yang cukup besar. Jadi ini sangat bermanfaat bila akan digunakan pada aplikasi yang sangat kritis terhadap beban dan tempat pemasangan. Menggunakan motor yang bertegangan (volt) rendah (dibawah $1000 \mathrm{kV}$ ), ini akan mempengaruhi agresifitas quadcopter dan efisiensi. Perkiraan juga beban yang diangkat motor. Ini akan menentukan pemilihan daya motor. Setiap motor punya daya dorong (trust), misalkan:

Motor dengan trust $960 \mathrm{gr}$ x $4=3840$ gr

Maka berat maksimal quadcopter $3 / 4$ x $3840 \mathrm{gr}=2880 \mathrm{gr}$
Perhitungan putaran (RPM) motor sebelum melakukan perencanaan perancangan quadcopter:

$$
\begin{aligned}
R P M & =k V \text { Motor } x \mathrm{~V} \text { Baterai }=980 \times 12 \\
& =11.760 R P M
\end{aligned}
$$

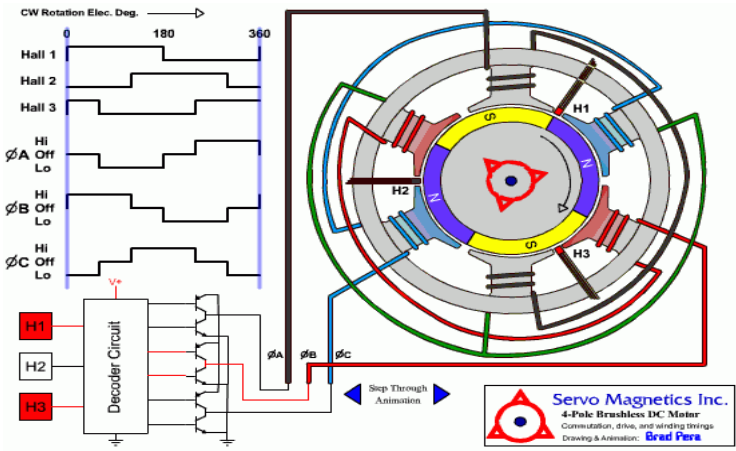

Gambar 2.8 Diagram Skema Motor Brushless

\section{PWM (Pulse Width Modulation)}

PWM merupakan suatu teknik dalam mengatur kerja suatu peralatan yang memerlukan aruss pull in yang besar dan untuk menghindari disipasi daya yang berlebihan dari peralatan yang akan dikontrol. PWM digunakan sebagai metode untuk mengatur kecepatan perputaran motor dengan cara mengatur persentase lebar pulsa high terhadap perioda dari suatu sinyal persegi dalam bentuk tegangan periodik yang diberikan ke motor sebagai sumber daya. Semakin besar perbandingan lama sinyal high dengan perioda sinyal maka semakin cepat motor akan berputar, perubahan PWM dipengaruhi oleh resolusi dari PWM tersebut.

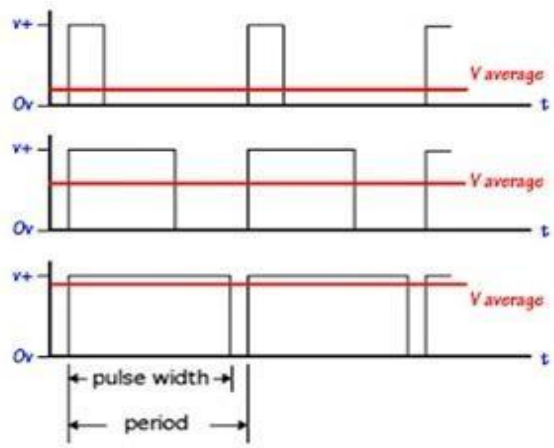

\section{Gambar 2.9 Proses Pembangkitan Sinyal PWM}

Resolusi adalah jumlah variasi perubahan nilai dalam PWM tersebut. Misalkan suatu PWM memiliki resolusi 8 bit berarti PWM memiliki variasi perubahan sebanyak 2 pangkat $8=256$ variasi, mulai dari $0 \mathrm{~s} / \mathrm{d} 255$ perubahan nilai. Compare adalah nilai pembanding, nilai ini merupakan nilai referensi duty cycle dari PWM tersebut dan nilai compare bervariasi sesuai dengan resolusi dari PWM. Pada gambar 2.19 nilai compare ditandai dengan garis warna merah, dimana posisinya diantara dasar segitiga dan ujung segitiga. Clear digunakan untuk penentuan jenis komparator apakah komparator inverting atau non-inverting. Mikrokontroler akan membandingkan posisi keduanya, misalkan bila PWM 
diset pada kondisi clear down, berarti apabila garis segitiga berada dibawah garis merah (compare) maka PWM akan mengeluarkan logika 0. Begitu pula sebaliknya apabila garis berada diatas garis merah (compare) maka PWM akan mengeluarkan logika 1. Lebar sempitnya logika 1 ditentukan oleh posisi compare, lebar sempitnya logika 1 itulah yang menjadi keluaran PWM. Maka dari itu nilai compare inilah yang dijadikan nilai duty cycle PWM. Clear UP adalah kebalikan dari Clear Down pada keluaran logikanya.

\section{METODOLOGI}

\section{Diagram alir}

Sebelum membuat perancangan dibutuhkan pemahaman urutan kerja dari alat yang akan dibuat, sehingga perancangan yang akan dibuat bisa berurutan dengan sesuai. Untuk lebih mudah terlebih dahulu merancang diagram alir prosedur perancangan seperti pada gambar 3.1.

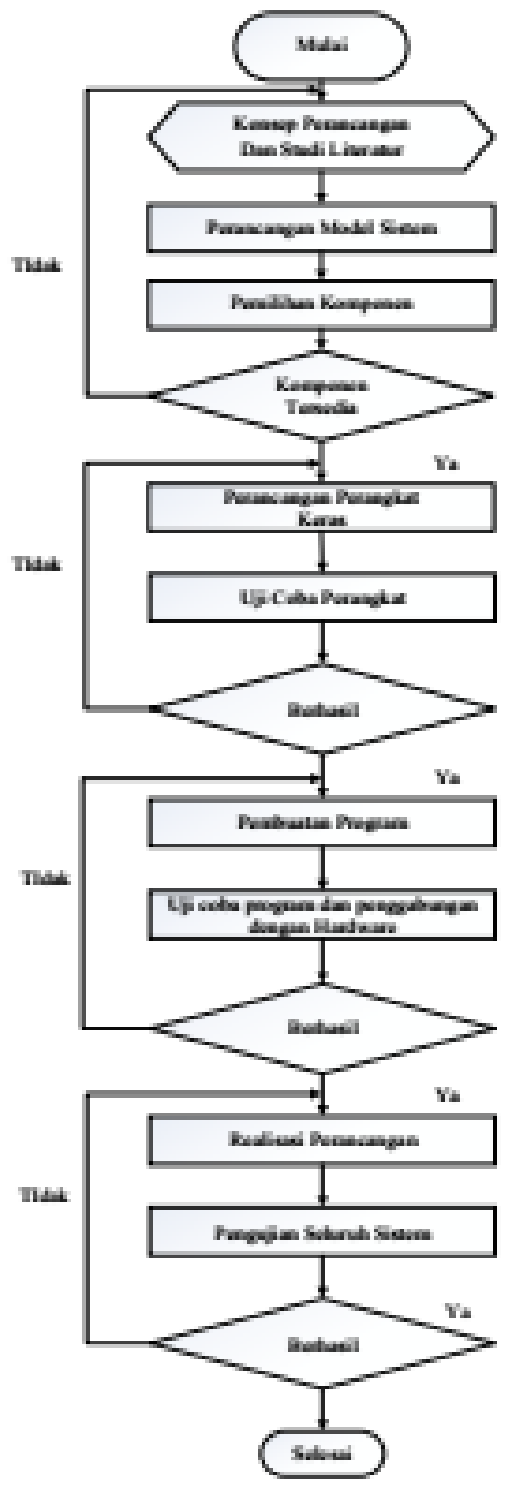

Gambar 3.1 diagram alir pengukuran

\section{Alat dan bahan}

Tabel 3.1 Alat dan bahan

\begin{tabular}{|c|c|c|c|}
\hline No & $\begin{array}{l}\text { Tools and } \\
\text { Materials }\end{array}$ & Jumlah & Fungsi \\
\hline 1. & $\begin{array}{l}\text { Flight Control APM } \\
2.8\end{array}$ & 1 & Sebagai sistem kontrol utama \\
\hline 2. & Frame F450-Q & 1 & Sebagai chasis quadcopter \\
\hline 3. & $\begin{array}{l}\text { Li-Po Batery Tiger } \\
\text { Power } 3500 \mathrm{mAh}\end{array}$ & 1 & Sebagai catu daya \\
\hline 4. & $\begin{array}{l}\text { Motor Brushless } \\
\text { SunnySky }\end{array}$ & 4 & Sebagai aktuator propeller \\
\hline 5. & $\begin{array}{l}\text { UBEC Hobywing 3A } \\
\max 5 \mathrm{~A}\end{array}$ & 1 & $\begin{array}{l}\text { Sebagai pengubah tegangan } \\
12 \text { v ke } 5 \mathrm{v}\end{array}$ \\
\hline 6. & Remote CX-20 & 1 & $\begin{array}{l}\text { Sebagai receiver masukan } \\
\text { nilai PWM dan transmiter } \\
\text { remote control }\end{array}$ \\
\hline 7. & ESC Opto $30 \mathrm{~A}$ & 4 & $\begin{array}{l}\text { Sebagai driver masukan daya } \\
\text { ke motor brushless }\end{array}$ \\
\hline 8. & IF Sensor to Arduino & 4 & Sebagai sensor RPM \\
\hline 9. & Arduino Nano & 1 & Sebagai sistem pengolahan \\
\hline 10. & Relay to Arduino & 2 & $\begin{array}{l}\text { Sebagai pengolahan RPM } \\
\text { keseluruhan }\end{array}$ \\
\hline 11. & Module Bluetooth & 1 & $\begin{array}{l}\text { Sebagai modul tambahan } \\
\text { untuk mengirimkan data ke }\end{array}$ \\
\hline 12. & Propeller Carbon & 4 & $\begin{array}{l}\text { Sebagai perangkat penunjang } \\
\text { pengarah angin }\end{array}$ \\
\hline 13. & Camera syma & 1 & $\begin{array}{l}\text { Sebagai alat penunjang untuk } \\
\text { melakukan peninjauan secara } \\
\text { live }\end{array}$ \\
\hline 14. & GPS & 1 & Sebagai Navigasi \\
\hline 15. & $\begin{array}{l}\text { Osiloscope GW } \\
\text { Instek } 5 \text { Chanel }\end{array}$ & 1 & Sebagai alat pengukur \\
\hline 16. & Tacho Meter & 1 & Sebagai alat pengukur RPM \\
\hline
\end{tabular}

\section{Diagram rangkaian}

Dalam merancang sistem quadcopter terdiri dari perancangan perangkat keras dan perangkat lunak. Perancangan perangkat keras terdiri dari blok masukkan berupa catu daya, sensor, sinyal RC, flight control, kamera, motor brushless, arduino nano, GPS, UBEC, ESC dan bluetooth. Untuk perancangan perangkat lunak menggunakan software mision planer untuk quadcopter serta arduino IDE untuk pengolahan data. 


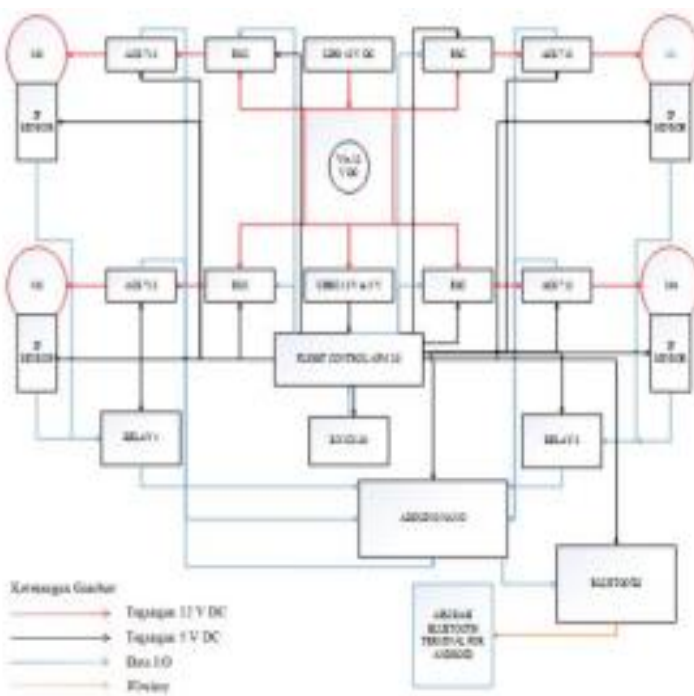

Gambar 3.2 Diagram rangkaian

\section{Posisi motor}

Skema letak motor penggerak pada masing-masing desain lengan quadcopter yang terdiri dari 4 buah motor penggerak yakni motor 1 , motor 2 , motor 3 dan motor 4 . Adapun skema letak motor dapat dilihat pada gambar 3.3

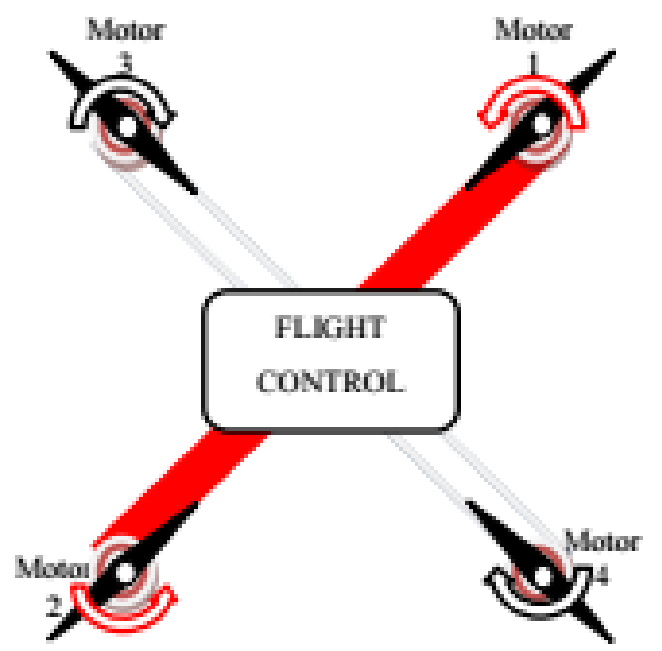

Gambar 3.3 Motor Position Scheme On Quadcopter

Pada gambar 3.3 diatas dapat dilihat skema letak motor pada quadcopter dimana setiap lengan quadcopter terdiri atas empat buah motor penggerak dan pada keempat buah motornya terpasang baling-baling (propeller). Dibagian tengah (pusat) dari desain quadcopter terletak mikrokontroller yang fungsinya sebagai sistem kontrol pada quadcopter tersebut.

\section{Flowchart RPM}

Adapun aturan untuk pengambilan data kecepatan (RPM) pada perancangan ini dapat dilihat pada gambar 3.4 dibawah:

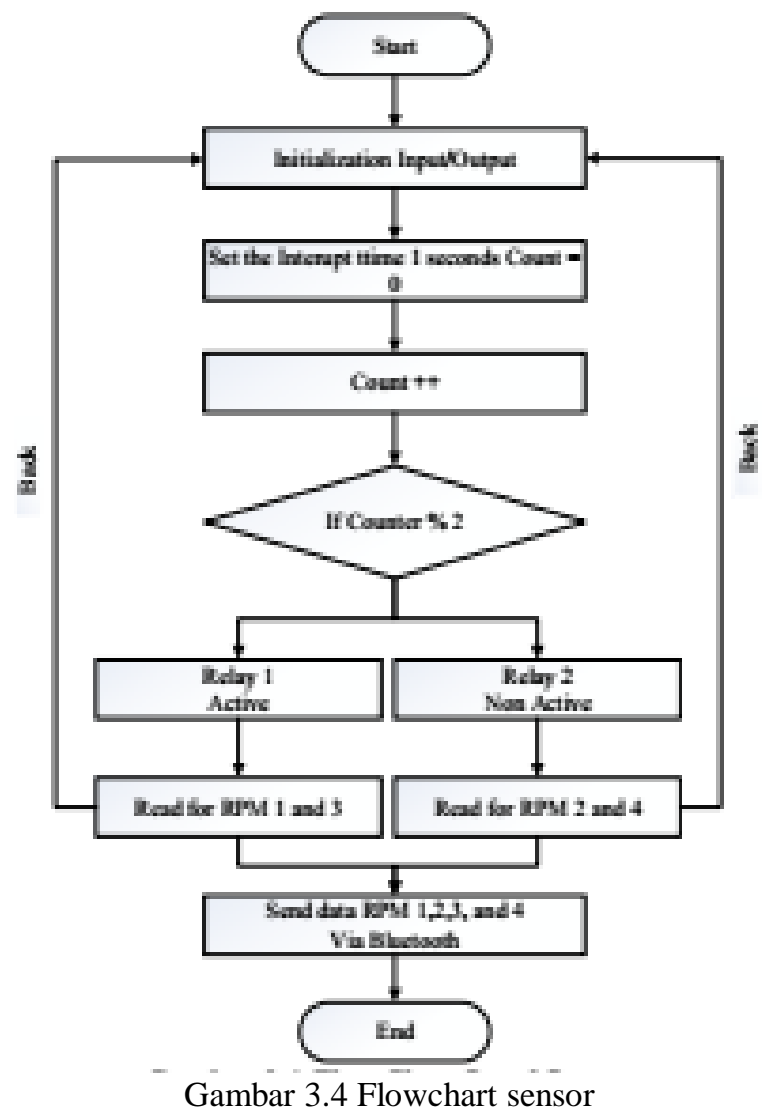

Pada proses flow chart diatas dilakukan set interupt pada arduino untuk menghitung besaran kecepatan (RPM) menggunakan counter agar mengetahui genap atau ganjil, pada proses perhitungan ini menggunakan komponen relay yang fungsinya untuk menghitung kecepatan (RPM) secara bergantian dengan range 1 detik, untuk lebih jelas dapat dilihat pada gambar 3.6 dibawah.

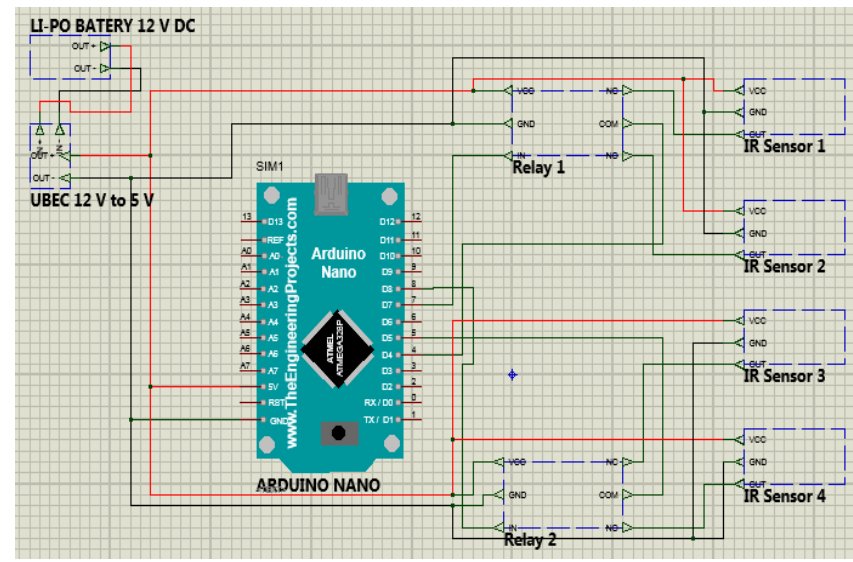

Gambar 3.5 Diagram rangkaian sensor 
Pada gambar 3.5 Diagram rangkaian sensor di atas sensor if terhubung ke reley kemudian output reley terhubung pada arduino pada pin 4,5 dan 7,8 yang memiliki interupt, untuk tegangan sensor diambil melalui tegangan keluaran ubec sebesar $5 \mathrm{v}$, sensor if diletakkan pada frame quadcopter yang berdekatan dengan propeller dengan tujuan pembacaan RPM dengan cara memantulkan cahaya ke propeller kemudian pantulan diserap oleh inframerah pada sensor.

\section{HASIL DAN PEMBAHASAN}

\section{Hasil Data Yang Diperoleh Dari Pengujian}

Hasil Data bentuk gelombang, Tegangan (V), Frekuensi (F), Perioda (S) pada setiap motor DC bruhless dari pembacaan gelombang. Adapun hasil data saat melakukan pengujian pada saat quadcopter melakukan operasi sesungguhnya dengan meletakkan asumsi-asumsi yang sudah ditetapkan pada saat sebelum melakukan pengujian dengan menggunakan media osiloscop dengan 4 buah chanel agar mempermudah saat melakukan pengujian serta pembacaan data, untuk lebih jelas dapat dilihat di bawah ini:

\section{Bentuk gelombang pitch move}

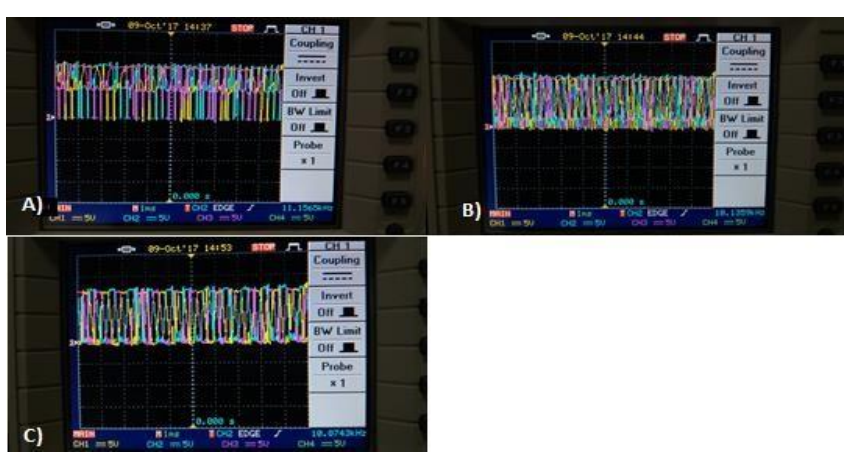

Gambar 4.1 Bentuk gelombang pada motor 1 A) Move $10 \%$, B) Move $50 \%$, C) Move $100 \%$

Gambar 4.1 diatas menunjukan hasil bentuk gelombang yang di tampilkan oleh osiloskop dalam hasil pengujian pada motor dengan bentuk gelombang warna merah phasa $\mathrm{A}$, biru phasa $\mathrm{B}$, dan kuning adalah phasa $\mathrm{C}$ dengan posisi gerak maju pada motor 1 dengan asumsi $10 \%, 50 \%$, dan $100 \%$ pada posisi ini motor 1 tidak terlihat kerapatan gelombangnya dikarenakan motor 2 dan 4 yang harus meningkatkan kecepatannya sehingga quadcopter mampu melalukan akselerasi maju sehingga kerapatan gelombang tampak pada gambar motor 2 dan 4 . Untuk data yang di peroleh pada gambar $4.2 \mathrm{~A}$ ) posisi pedal gas pada keadaan $10 \%$ untuk data tegangan (V) yang diperoleh sebesar phasa A $12,4 \mathrm{~V}$, phasa $\mathrm{B} 12,8 \mathrm{~V}$ dan phasa $\mathrm{C} 12,4 \mathrm{~V}$ untuk frekuensi (F) sebesar phasa A 7,153 kHz, phasa B 1,906 kHz, phasa $\mathrm{C} 3,52 \mathrm{kHz}$ dan untuk data perioda $(\mathrm{S})$ diperoleh phasa A $139,2 \mu \mathrm{s}$, phasa B 524,7 $\mu \mathrm{s}$, phasa C 282,2 $\mu \mathrm{s}$. Pada gambar $4.2 \mathrm{~B}$ ) keadaan pedal gas $50 \%$ data yang diperoleh untuk tegangan $(\mathrm{V})$ phasa A $12,2 \mathrm{~V}$, phasa $\mathrm{B} 12,8 \mathrm{~V}$, phasa C $12 \mathrm{~V}$ untuk frekuensi diperoleh phasa A 4,634 kHz phasa
B 3,639 kHz , phasa C 5,562 kHz dan perioda phasa A 215,8 $\mu \mathrm{s}$, phasa B 274,7 $\mu \mathrm{s}$, phasa C $179 \mu \mathrm{s}$. Pada gambar $4.2 \mathrm{C}$ ) keadaan pedal gas pada posisi $100 \%$ data tegangan $(\mathrm{V})$ yang diperoleh phasa A $12,4 \mathrm{~V}$, phasa B $12,6 \mathrm{~V}$, phasa $\mathrm{C} 12,4 \mathrm{~V}$, untuk frekuensi (F) phasa A 2,321 kHz, phasa B $6,103 \mathrm{kHz}$, phasa $\mathrm{C} 9,037 \mathrm{kHz}$, dan data perioda (S) diperoleh phasa $\mathrm{A}$ $430,9 \mu \mathrm{s}$, phasa B $163,9 \mu \mathrm{s}$, phasa $\mathrm{C} 110,7 \mu \mathrm{s}$. data ini diperoleh dengan pengaturan pembacaan time/div sebesar 1 ms.

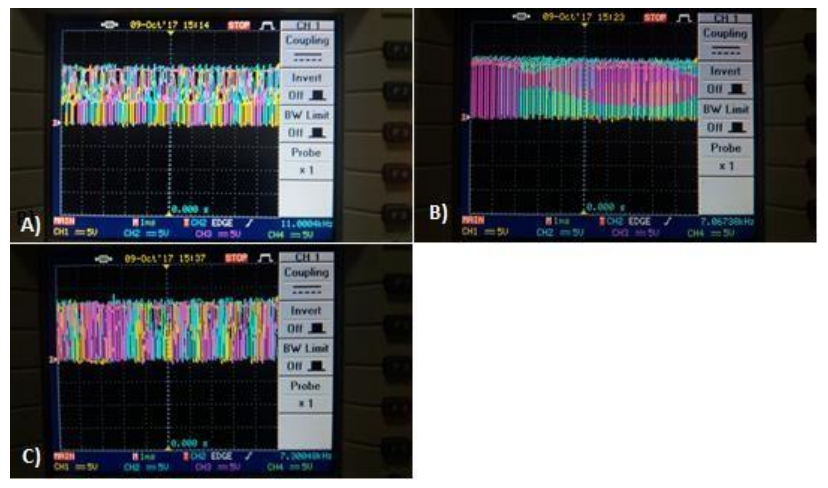

Gambar 4.2 Bentuk gelombang pada motor 2 A) Move 10\%, B) Move $50 \%$, C) Move $100 \%$

Gambar 4.2 diatas menunjukan hasil bentuk gelombang yang di tampilkan oleh osiloskop dalam hasil pengujian pada motor dengan bentuk gelombang warna merah phasa $\mathrm{A}$, biru phasa $\mathrm{B}$, dan kuning adalah phasa $\mathrm{C}$ dengan posisi gerak maju pada motor 2 dengan asumsi $10 \%$, $50 \%$, dan $100 \%$ dimana pada posisi $100 \%$ kecepatan motor 2 meningkat sehingga kerapatan gelombangpun terjadi di sebabkan oleh pada posisi pitch move motor 2 dan 4 yang meningkat kecepatannya. Untuk data yang di peroleh pada gambar 4.3 A) posisi pedal gas keadaan $10 \%$ untuk data tegangan (V) diperoleh sebesar phasa A $12 \mathrm{~V}$, phasa B $12,6 \mathrm{~V}$ dan phasa C 12,2 V untuk frekuensi (F) sebesar phasa A $3,498 \mathrm{kHz}$, phasa B $1,170 \mathrm{kHz}$, phasa $\mathrm{C} 3,519 \mathrm{kHz}$ dan untuk data perioda (S) diperoleh phasa A $285,8 \mu \mathrm{s}$, phasa B $855 \mu \mathrm{s}$, phasa C 284,1 $\mu$ s. Pada gambar 4.3 keadaan pedal gas $50 \%$ data yang diperoleh untuk tegangan (V) phasa A $12 \mathrm{~V}$, phasa B $12,4 \mathrm{~V}$, phasa C $12 \mathrm{~V}$ untuk frekuensi diperoleh phasa A $4,634 \mathrm{kHz}$ phasa $\mathrm{B}$ $9,098 \mathrm{kHz}$, phasa C $5,074 \mathrm{kHz}$ dan perioda $(\mathrm{S})$ phasa A 613,9 $\mu \mathrm{s}$, phasa B 897,6 $\mu \mathrm{s}$, phasa C 197 us. Pada gambar $4.3 \mathrm{C}$ ) keadaan pedal gas pada posisi $100 \%$ data tegangan (V) yang diperoleh phasa A $11,8 \mathrm{~V}$, phasa B $12 \mathrm{~V}$, phasa C 11,6 V, untuk frekuensi $(\mathrm{F})$ phasa $\mathrm{A} 1,250 \mathrm{kHz}$, phasa $\mathrm{B}$ $1,244 \mathrm{kHz}$, phasa $\mathrm{C} 1.250 \mathrm{kHz}$, dan data perioda $(\mathrm{S})$ diperoleh phasa A $125 \mu \mathrm{s}$, phasa B $808 \mu \mathrm{s}$, phasa C 804,1 $\mu$ s. data ini diperoleh dengan pengaturan pembacaan time/div sebesar $1 \mathrm{~ms}$. 


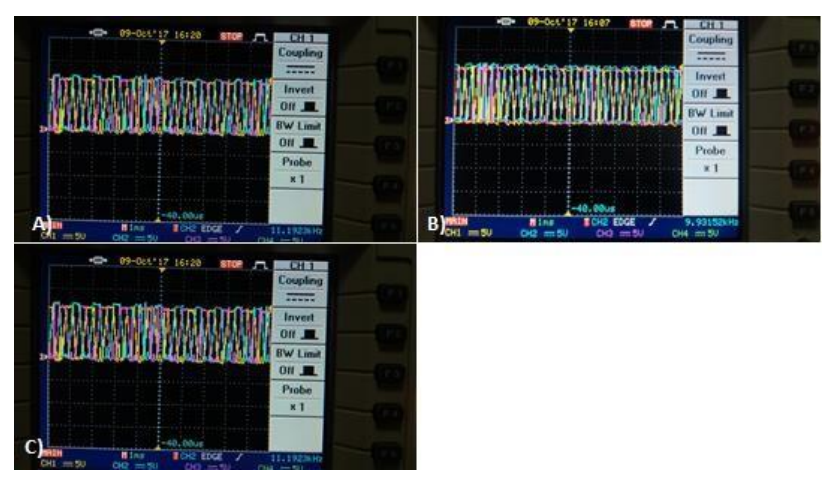

Gambar 4.3 Bentuk gelombang pada motor 3

A) Move 10\%, B) Move $50 \%$, C) Move $100 \%$

Gambar 4.3 di atas menunjukan hasil bentuk gelombang yang di tampilkan oleh osiloskop dalam hasil pengujian pada motor 3 dengan bentuk gelombang warna merah phasa $\mathrm{A}$, biru phasa $\mathrm{B}$, dan kuning adalah phasa $\mathrm{C}$ dengan posisi gerak maju pada motor 3 dengan asumsi $10 \%, 50 \%$, dan $100 \%$ pada posisi pitch move kerapatan gelombang tidak kelihatan pada motor 3 dikarenakan pada posisi ini motor yang meningkatkan kecepatan hanya pada motor 2 dan 4 sehingga kerapatan jelas kelihatan pada bentuk glombang motor 2 dan 4. Untuk data yang di peroleh pada gambar $4.4 \mathrm{~A}$ ) posisi pedal gas keadaan $10 \%$ untuk data tegangan (V) diperoleh sebesar phasa A $12,6 \mathrm{~V}$, phasa B $13 \mathrm{~V}$ dan phasa C 12,4 V untuk frekuensi (F) sebesar phasa A 9,462 kHz, phasa B $2,318 \mathrm{kHz}$, phasa C $1,194 \mathrm{kHz}$ dan untuk data perioda (S) diperoleh phasa A $105,7 \mu \mathrm{s}$, phasa B 431,4 $\mu \mathrm{s}$, phasa C 837,5 $\mu$ s. Pada gambar 4.4 B) keadaan pedal gas $50 \%$ data yang diperoleh untuk tegangan $(\mathrm{V})$ phasa $\mathrm{A} 12,6 \mathrm{~V}$, phasa $\mathrm{B} 13 \mathrm{~V}$, phasa $\mathrm{C} 12,4 \mathrm{~V}$ untuk frekuensi diperoleh phasa $\mathrm{A} 1,114 \mathrm{kHz}$ phasa B $1,044 \mathrm{kHz}$, phasa C $1.048 \mathrm{kHz}$ dan perioda (S) phasa A 897,6 $\mu \mathrm{s}$, phasa B 958,2 $\mu \mathrm{s}$, phasa C 954,2 $\mu \mathrm{s}$. Pada gambar $4.4 \mathrm{C}$ ) keadaan pedal gas pada posisi $100 \%$ data tegangan yang diperoleh phasa A $12,4 \mathrm{~V}$, phasa B $13 \mathrm{~V}$, phasa $\mathrm{C} 12,2 \mathrm{~V}$, untuk frekuensi $(\mathrm{F})$ phasa $\mathrm{A} 1,528 \mathrm{kHz}$, phasa B $1,052 \mathrm{kHz}$, phasa C 2,617kHz, dan data perioda (S) diperoleh phasa A $654,6 \mu \mathrm{s}$, phasa B 950,8 $\mu \mathrm{s}$, phasa C 328 $\mu \mathrm{s}$. data ini diperoleh dengan pengaturan pembacaan time/div sebesar $1 \mathrm{~ms}$.

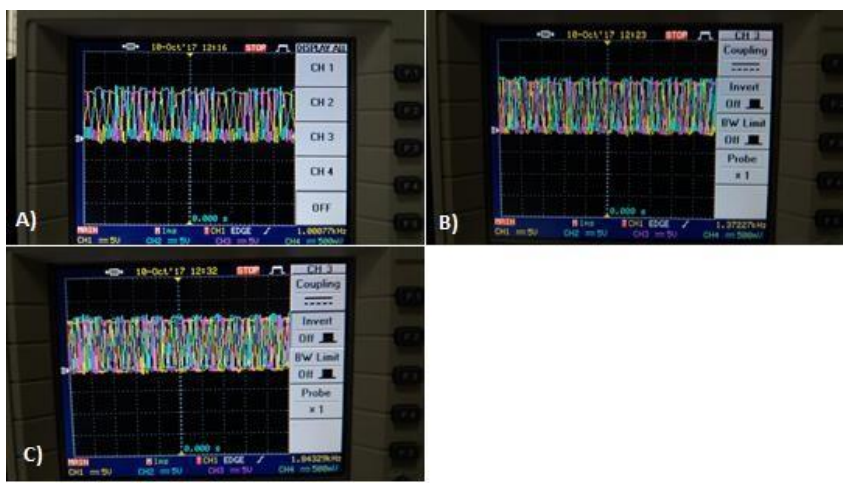

Gambar 4.4 diatas menunjukan hasil bentuk gelombang yang di tampilkan oleh osiloskop dalam hasil pengujian pada motor 4 dengan bentuk gelombang warna merah phasa $\mathrm{A}$, biru phasa $\mathrm{B}$, dan kuning adalah phasa $\mathrm{C}$ dengan posisi gerak maju pada motor 4 dengan asumsi $10 \%, 50 \%$, dan $100 \%$ dimana pada posisi move dalam keadaam $100 \%$ kecepatan pada motor 4 meningkat dikarenakan karena pada posisi pitch move quadcopter melakukan akselerasi maju sehingga quadcopter meningkatkan kecepatan motor pada motor 2 dan 4. Untuk data yang di peroleh pada gambar $4.5 \mathrm{~A})$ posisi pedal gas keadaan $10 \%$ untuk data tegangan $(\mathrm{V})$ diperoleh sebesar phasa A $12,4 \mathrm{~V}$, phasa B $12,6 \mathrm{~V}$ dan phasa $\mathrm{C} 12,6 \mathrm{~V}$ untuk frekuensi (F) sebesar phasa A $2,217 \mathrm{kHz}$, phasa B $5,884 \mathrm{kHz}$, phasa $\mathrm{C} 1,180 \mathrm{kHz}$ dan untuk data perioda (S) diperoleh phasa A 440,2 $\mu$ s, phasa B $169,9 \mu \mathrm{s}$, phasa C 847,3 $\mu \mathrm{s}$. Pada gambar $4.5 \mathrm{~B}$ ) keadaan pedal gas $50 \%$ data yang diperoleh untuk tegangan (V) phasa A $12,6 \mathrm{~V}$, phasa B 12.4 $\mathrm{V}$, phasa $\mathrm{C} 12 \mathrm{~V}$ untuk frekuensi (F) diperoleh phasa A 2,372 $\mathrm{kHz}$ phasa B $1,378 \mathrm{kHz}$, phasa C $1.009 \mathrm{kHz}$ dan perioda (S) phasa A 421,5 $\mu \mathrm{s}$, phasa B 725,5 $\mu \mathrm{s}$, phasa C 991,4 $\mu \mathrm{s}$. Pada gambar $4.5 \mathrm{C}$ ) keadaan pedal gas pada posisi $100 \%$ data tegangan $(\mathrm{V})$ yang diperoleh phasa A $12,6 \mathrm{~V}$, phasa B 12,8 $\mathrm{V}$, phasa $\mathrm{C} 12,4 \mathrm{~V}$, untuk frekuensi $(\mathrm{F})$ phasa $\mathrm{A} 1,036 \mathrm{kHz}$, phasa $\mathrm{B} 9,288 \mathrm{kHz}$, phasa $\mathrm{C} 9,939 \mathrm{kHz}$, dan data perioda $(\mathrm{S})$ diperoleh phasa A $965,7 \mu \mathrm{s}$, phasa B $107,7 \mu \mathrm{s}$, phasa C 100,6 $\mu \mathrm{s}$. data ini diperoleh dengan pengaturan pembacaan time/div sebesar $1 \mathrm{~ms}$.

\section{Hasil Data RPM Pada Masing-Masing Motor Brushless}

\section{RPM pitch move}

Adapun data kecepatan RPM dari M1, M2, M3 dan M4 brushless pada keadaan possi manuver pitch move (gerak maju) dapat dilihat pada tabel 4.1.

Tabel 4.1 RPM Pada Manuver Pitch Move

\begin{tabular}{|c|c|c|c|c|}
\hline $\begin{array}{c}\text { Posisi } \\
\text { Remote }\end{array}$ & M1 & M2 & M3 & M4 \\
\hline $\mathbf{1 0} \%$ & 5125 & 6764 & 5034 & 6674 \\
\hline $\mathbf{5 0} \%$ & 8475 & 9982 & 8979 & 9560 \\
\hline $\mathbf{1 0 0} \%$ & 9935 & 10533 & 9130 & 10357 \\
\hline
\end{tabular}

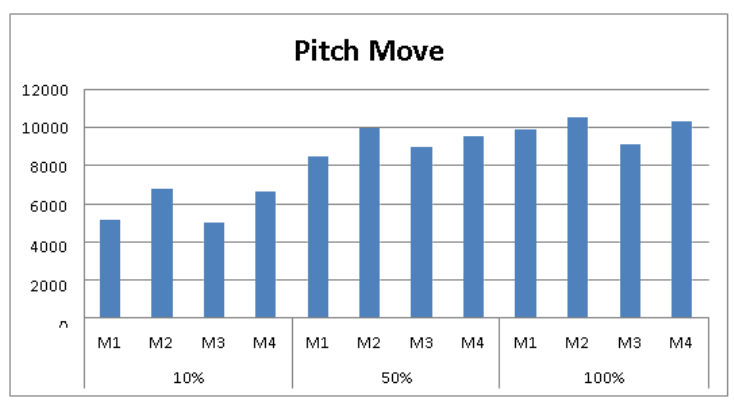

Gambar 4.5 RPM Motor pada Posisi Pitch Move

Gambar 4.4 Bentuk gelombang pada motor 3 A)Move $10 \%$, B) Move $50 \%$, C) Move $100 \%$ 
Hasil data tabel 4.1 dan gambar grafik 4.5 diatas terlihat untuk pergerakkan pitch move, motor 2 dan motor 4 terlihat lebih meningkat jumlah putarannya dibanding dengan kecepatan putaran motor 1 dan 3, dimana kecepatan pada saat $10 \%$ motor 2 dan 4 mencapai 6500 RPM, untuk $50 \%$ kecepatan motor 2 dan 4 lebih meningkat hingga mencapai 9500 RPM, dan saat $100 \%$ dimana posisi ini adalah maksimum dari pedal gas RPM pada motor 2 dan 4 mencapai 10300.

RPM pitch back

Adapun data kecepatan RPM dari M1, M2, M3 dan M4 brushless pada keadaan possi manuver pitch back (gerak mundur) dapat dilihat pada tabel 4.2

Tabel 4.2 RPM Pada Manuver Pitch Back

\begin{tabular}{|c|c|c|c|c|}
\hline $\begin{array}{c}\text { Posisi } \\
\text { Remote }\end{array}$ & M1 & M2 & M3 & M4 \\
\hline $\mathbf{1 0} \%$ & 5802 & 5193 & 5309 & 4655 \\
\hline $\mathbf{5 0} \%$ & 9862 & 8633 & 9735 & 8564 \\
\hline $\mathbf{1 0 0} \%$ & 10432 & 9012 & 10527 & 9929 \\
\hline
\end{tabular}

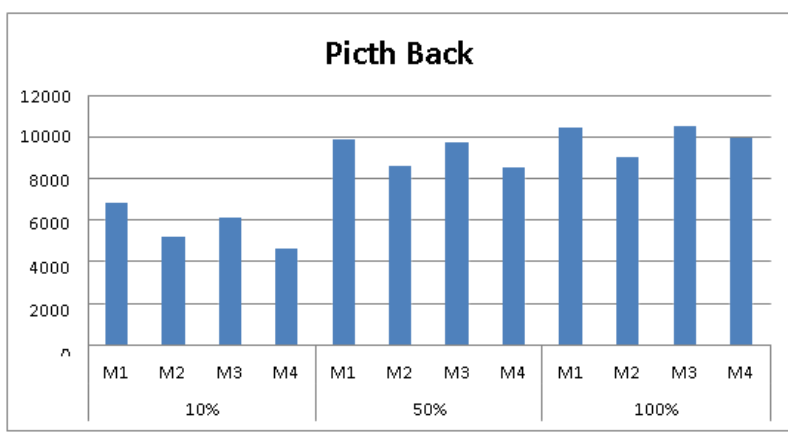

Gambar 4.6 RPM Motor pada Posisi Pitch Back

Hasil data tabel 4.63 dan gambar grafik 4.31 diatas terlihat untuk pergerakkan mundur motor 1 dan motor 3 terlihat lebih meningkat jumlah putarannya dibanding dengan kecepatan putaran motor 2 dan 4, dimana kecepatan pada saat $10 \%$ motor 1 dan 3 mencapai 6100 RPM, untuk $50 \%$ kecepatan motor 1 dan 3 lebih meningkat hingga mencapai 9700 RPM dimana posisi ini pedal gas berada di titik tengah, dan saat $100 \%$ dimana posisi ini adalah maksimum dari pedal gas RPM pada motor 1 dan 3 mencapai 10400.

\section{KESIMPULAN}

Adapun beberapa kesimpulan yang dapat ditarik dari penelitian ini adalah:

1. Dari hasil analisa diatas pengaruh manuver pada masing-masing motor mengalami perubahan kecepatan putaran motor yang dipengaruhi oleh pwm yang diberikan oleh flight control sesuai dengan manuver yang diperintahkan oleh remote control.
2. Motor brushless sumber DC 3 phasa diatur oleh ESC sehingga terjadi perubahan frekuensi pada setiap phasanya yang berada di keluaran ESC pada setiap motor, dengan keluaran frekuensi sebesar diatas $1 \mathrm{kHz}$.

3. Untuk gelombang keluaran ESC adalah gelombang dengan bentuk persegi dengan memiliki beda phasa pada setiap keluaran ESC. Dan Kearapatan bentuk gelombang yang ditampilkan osiloskop terlihat jelas bahawa semakin rapat gelombang maka putaran motor akan semakin kencang.

4. Untuk putaran motor brushless jenis sunny sky dengan tipe X2212-13 kv:980 II sesuai dengan kapasitas yang sudah dihitung, dan motor ini sesuai dengan design awal untuk mengangkat beban quadcopter yang mencapai $\pm 2 \mathrm{~kg}$.

\section{REFERENSI}

[1] Bresciani, T. (2008). Modelling, Identification and Control. 2008 [2] Gani, F. N. (2012, Novembver 7). Dipetik Agustus 6, 2017, dari http://robotic- electric.blogspot.co.id: http://roboticelectric.blogspot.co.id/2012/11/pulse-width-modulationpwm.html

[3] Mohammad Giffari Anta Pradana, R. P. (November 2016) SINGLE PROPELLER DRONE (SINGRONE): INOVASI RANCANG BANGUN DRONE SINGLE PROPELLER SEBAGAI WAHANA PEMETAAN LAHAN BERBAI UNMANNED AERIAL VEHICLE (UAV). JurnalElektronics, Informatics, and Vocational Education (ELINVO), Volume 1, Nomor 3, 157-162.

[4] Mr.Kalpesh N.Shah, M. B. (2014). "Quadrotor-An Unmanned Aerial Vehicle".IJEDR|Volume 2, Issue 1|ISSN:2321-9939, 1299 1303.

[5] Nurhayati. (2014). IMPLEMENTASI PID KONTROL UNTUK MENGONTROL KESTABILAN POSISI QUADCOPTER GUNA MENGIDENTIFIKASI OBJEK DARI KETINGGIAN MAKSIMAL 6 METER. Palembang: http://eprints.polsri.ac.id.

[6] Prakoso, T. B. (2015). IMPLEMENTASI DJI NAZA M-LITE PADA QUADCOPTER. Jurnal Ilmiah Mikrotek Vol. 1, No. 4, 193. 